\title{
The effect of garlic oil, xylanase enzyme and yeast on biomethane and carbon dioxide production from 60-d old Holstein dairy calves fed a high concentrate diet
}

\author{
A. Hernandez ${ }^{\text {a }}$, A.E. Kholif ${ }^{b}$, R. Lugo-Coyote ${ }^{\text {a }}$, M.M.Y. Elghandour ${ }^{\text {a }}$, M. Cipriano ${ }^{\text {, }}$, \\ G.B. Rodríguez ${ }^{\mathrm{d}}$, N.E. Odongo ${ }^{\mathrm{e}}$, A.Z.M. Salem ${ }^{\mathrm{a}}{ }^{*}$ \\ ${ }^{a}$ Facultad de Medicina Veterinaria y Zootecnia, Universidad Autónoma del Estado de México, México \\ b Dairy Science Department, National Research Centre, 33 Bohouth St. Dokki, Giza, Egypt \\ ${ }^{\mathrm{c}}$ Unidad Académica de Medicina Veterinaria y Zootecnia, Universidad Autónoma de Guerrero, Altamirano, P.0. 40660, México \\ ${ }^{\mathrm{d}}$ CENID-Fisiología y Mejoramiento Animal, INIFAP, Ajuchitlán, Querétaro, México \\ e Department of Animal Sciences, School of Agriculture, Pwani University, P. O. Box, 195-80108, Kilifi, Kenya
}

\section{A R T I C L E I N F O}

\section{Article history:}

Received 14 August 2016

Received in revised form

7 October 2016

Accepted 6 November 2016

Available online 8 November 2016

\section{Keywords:}

Garlic oil

Greenhouse gases

Methane mitigation

Xylanase

Yeast

\begin{abstract}
A B S T R A C T
Ruminal fermentation is accompanied by production of methane $\left(\mathrm{CH}_{4}\right)$ and carbon dioxide $\left(\mathrm{CO}_{2}\right)$ which are greenhouse gases (GHG) that cause environmental pollution. The effect of natural feed additives on the in vitro fermentation and production of $\mathrm{CH}_{4}$ and $\mathrm{CO}_{2}$ in dairy calf has had less attention. Therefore, this study aimed to evaluate the effect of garlic oil, xylanase enzyme, and yeast on in vitro biogas production from dairy calves fed a high concentrate diet. Rumen contents from 60-d old Holstein calves fed a concentrate diet were used as inoculum source. Garlic oil was included at 30,120, 250 and $500 \mu \mathrm{L} / \mathrm{g}$ dry matter (DM), while xylanase was included at 3 and $6 \mu \mathrm{L} / \mathrm{g}$ DM and yeast at 2 and $4 \mathrm{mg} / \mathrm{g}$ DM. The substrate used was the same as the diet fed to calves. Garlic oil linearly decreased $(P<0.05)$ in vitro DM digestibility and there were no differences among levels of either xylanase or yeast. Garlic oil decreased $(P<0.05)$ DM degradability while xylanase and yeast had no effect. The lag phase was linearly increased $(P<0.05)$ with increasing level of garlic oil. Garlic oil quadratically decreased $\mathrm{CH}_{4}$ and $\mathrm{CO}_{2}$ production. The control treatment had the highest $\mathrm{CH}_{4}$ and $\mathrm{CO}_{2}$ production followed by xylanase, yeast and garlic oil. Increasing level of xylanase and yeast increased $(P<0.05) \mathrm{CO}_{2}$ production. It can be concluded that garlic oil followed by yeast and then xylanase can be used to mitigate in vitro $\mathrm{CH}_{4}$ and $\mathrm{CO}_{2}$ production from dairy calves fed a high concentrate diet. However, further research is warranted to establish the efficacy of such feed additives in in vivo trials.
\end{abstract}

() 2016 Elsevier Ltd. All rights reserved.

\section{Introduction}

Ruminant nutritionists aim to manipulate the ruminal microbial ecosystems and fermentation to improve feed utilization and feed conversion to animal products. Antibiotics have good effects on feed utilization and production, but have been banned due to the

\footnotetext{
Abbreviations: ADF, acid detergent fiber; $b$, the asymptotic gas production; $c$, the fractional rate of fermentation; $\mathrm{CH}_{4}$, methane; $\mathrm{CO}_{2}$, carbon dioxide; $\mathrm{CP}$, crude protein; DM, dry matter; DMD, dry matter degradability; EE, ether extract; GHG, greenhouse gas; GP, gas production; Lag, the discrete lag time prior to any gas being released; $\mathrm{N}$, nitrogen; $\mathrm{NDF}$, neutral detergent fiber; $\mathrm{O}_{2}$, oxygen.

* Corresponding author.

E-mail address: asalem70@yahoo.com (A.Z.M. Salem).
}

increasing public concern for their usage. Thus, looking for natural alternative has gained interest and importance. Phytogenic extracts (Cedillo et al., 2015), exogenous enzymes (Vallejo et al., 2016), and yeast (Hassan et al., 2016) are gaining increasing interest as feed additive for animal feeding. Such feed additives can reduce energy losses as methane $\left(\mathrm{CH}_{4}\right)$, and nitrogen $(\mathrm{N})$ as ammonia, which reduce animal performance and contribute to the release of pollutants to the environment.

Currently, the livestock production sector is one of the largest contributors of anthropogenic sources of greenhouse gases (GHG), where livestock production accounts approximately for two-thirds of the direct emissions (Slade et al., 2016). Methane is the most important GHG since it accounts for about $50-60 \%$ of emitted GHG; it is also responsible for a loss of about $2-12 \%$ of gross energy of 
feed in ruminant production systems (Mirzaei-Aghsaghali et al., 2012). Thus, it is important to reduce enteric $\mathrm{CH}_{4}$ production in ruminants and contribute to reduce global GHG emissions without any negative effect on feed conversion efficiency.

Garlic (Allium sativum) has been shown to have positive effects on nutrient digestibility and antimicrobial activity in ruminant feeding. Garlic oil contains several active compounds, including organosulfur compounds, enzymes, sterols, steroids, triterpenoid glycosides, flavonoids, phenols, and organoselenium compounds (Lawson, 1996). The use of garlic oil as a feed additive in ruminant nutrition has not been researched until recently. In some experiments (Busquet et al., 2005; Mirzaei-Aghsaghali and Maheri-Sis, 2011), garlic oil reduced the concentration of short chain fatty acids and proportions of acetate, and increased the proportions of propionate and butyrate, with inhibition of $\mathrm{CH}_{4}$ production. However, garlic oil has antimicrobial activity, which may be detrimental to ruminal fermentation at high levels (Busquet et al., 2005). The antimicrobial activity is related mainly to the active components in garlic oil (i.e., organosulfur compounds) which caused reduced $\mathrm{CH}_{4}$ proportions, revealing its role in rumen microbial modulation (Busquet et al., 2005). Busquet et al. (2005) suggested that the antimethanogenic effect of garlic is due to its active components which have direct inhibition on Archaea microorganisms in the rumen. However, the mechanism by which garlic decreases $\mathrm{CH}_{4}$ production is not known; although the mechanism could be related to the capacity of organosulfur compounds to inhibit the enzyme 3hydroxy-3-methylglutaryl coenzyme A reductase by a thioldisulfide exchange reaction (Gebhardt and Beck, 1996).

Feeding ruminants on diets supplemented with fiberdegrading enzymes has been shown to improve feed utilization and animal performance (Rojo et al., 2015; Morsy et al., 2016), although the mode of action has not been fully elucidated. However, hydrolysis of dietary fiber and alteration of ruminal fermentation (Alsersy et al., 2015), and enhanced ruminal microorganisms attachment and colonization to the plant cell wall (Wang et al., 2001) were observed. Synergistic enhancement of microbial enzyme activity in the rumen (Morgavi et al., 2000) have been suggested as possible modes of action. Morgavi et al. (2000) demonstrated a synergism between exogenous and endogenous rumen enzymes. The net result was a higher hydrolytic effect in the rumen with combined enzymes than that estimated from individual enzyme activities.

Saccharomyces cerevisiae is generally recognized as safe by the Food and Drug Administration organization of USA, and it can be legally used as an animal feed additive to stabilize rumen fermentation and prevents rumen microflora disorders (Elghandour et al., 2015; Hassan et al., 2016). Yeast has the ability to modify ruminal fermentation through provision of important nutrients and nutritional cofactors required for microbial growth and activity (Polyorach et al., 2014). Besides, yeast could enhance fungal colonization of plant cell walls resulting in increased dry matter (DM) and neutral detergent fiber (NDF) digestion (Patra, 2012) and mitigate $\mathrm{CH}_{4}$ production due to stimulation of the acetogens to compete or co-metabolize hydrogen $\left(\mathrm{H}_{2}\right)$ with methanogens, thereby reducing $\mathrm{CH}_{4}$ emissions (Hristov et al., 2013).

To the best of our knowledge, no study has been carried out to test the effect of natural feed additives on the in vitro fermentation of feeds using rumen inoculum from calves. Besides, the in vitro biogases produced (e.g., $\mathrm{CH}_{4}$ and carbon dioxide $\left(\mathrm{CO}_{2}\right)$ ) from dairy calves has not been investigated before. Therefore, the present experiment aimed to investigate the effect of natural feed additives i.e. garlic oil, xylanase enzyme and yeast at different levels on in vitro biogases production from 60-d old dairy calves fed a high concentrate diet.

\section{Materials and methods}

\subsection{Treatments}

Three feed additives were tested against a control treatment (no additives): garlic oil (Garlic oil, Chinese, Sigma-Aldrich, Saint Louis, MO, USA) at 30,120, 250 and $500 \mu \mathrm{L} / \mathrm{g}$ DM, xylanase (Dyadic ${ }^{\circledR}$ Xylanase PLUS, Dyadic International, Inc., Jupiter, USA) at 3 and $6 \mu \mathrm{L} / \mathrm{g}$ DM and yeast (Procreatin 7, Safmix, Toluca, Mexico) at 2 and $4 \mathrm{mg} / \mathrm{g}$ DM. The substrate used was the same diet fed to calves.

\subsection{In vitro incubations}

Rumen inoculum was collected before morning feeding from 6 weaned calves at 60 days of age with $40-55 \mathrm{~kg}$ body weight using a stomach tube and hand pump. Calves were fed ad libitum a starter feed of a total mixed ration of a commercial concentrate (Ultra Malta Clayton $^{\circledR}$, Toluca, Mexico) containing (g/kg DM): 200 crude protein (CP), 230 NDF, 50.3 acid detergent fiber (ADF) and 35.6 either extract (EE). The starter feed was formulated to meet the calves' nutrient requirements as per the National Research Council (NRC, 2001). Calves had free access to fresh water at all times during inoculum collection phase. Immediately after collection, the rumen contents from each calf were flushed with $\mathrm{CO}_{2}$, mixed and strained through four layers of cheesecloth into a flask with an oxygen $\left(\mathrm{O}_{2}\right)$ free headspace. Filtered rumen fluid was immediately transported to the laboratory where it was mixed in a $1: 4(\mathrm{v} / \mathrm{v})$ ratio with the buffer solution as described by Goering and Van Soest (1970), with no trypticase added. Diluted rumen fluid ( $40 \mathrm{~mL}$ containing $10 \mathrm{~mL}$ of rumen liquor) was added to each incubation bottle, where substrates ( $0.5 \mathrm{~g} \mathrm{DM})$ had been previously weighed out and additive solutions dispensed.

Three incubation runs were performed in three different weeks. In addition to bottles containing substrate, three bottles were incubated as blanks (i.e., rumen fluid only, with no substrate). After filling all bottles, they were immediately closed with rubber stoppers, shaken and placed in a water bath at $39^{\circ} \mathrm{C}$. The volume of gas production (GP) was recorded at 2, 4, 6, 8, 10, 12, 14, 16, 18, 24, 36, 48,60 and $72 \mathrm{~h}$ of incubation using a pressure transducer (Extech Instruments, Waltham, USA) following the technique of Theodorou et al. (1994). At the same incubation period, $\mathrm{CH}_{4}$ and $\mathrm{CO}_{2}$ concentrations in the headspace of the bottles was measured using a diffusion based gas detector (Gas Analyzer CROWCON Model Tetra3, Abingdon, UK).

After sampling the supernatant and $\mathrm{pH}$ determination, the content of each bottle was filtered under vacuum through sintered glass crucibles (coarse porosity no. 1, pore size 100-160 $\mu \mathrm{m}$; Pyrex, Stone, UK) and incubation residues dried at $105{ }^{\circ} \mathrm{C}$ overnight to estimate apparent DM degradability (DMD).

\subsection{Chemical analyses}

Samples of feeds were analyzed for DM (\#934.01), ash (\#942.05), N (\#954.01) and EE (\#920.39) using AOAC (1997) official methods. The NDF (Van Soest et al., 1991) and ADF (AOAC, 1997; \#973.18) contents in both feeds and incubation residues were determined using an ANKOM $^{200}$ Fiber Analyzer Unit (ANKOM Technology Corp., Macedon, NY, USA). The NDF analysis was done with sodium sulfite, and with $\alpha$-amylase. Both NDF and ADF were expressed without residual ash.

\subsection{Calculations and statistical analyses}

To estimate kinetic parameters of GP, gas volumes recorded ( $\mathrm{mL} /$ g DM) were fitted using the NLIN procedure of SAS (2002) 
according to France et al. (2000) model as:

$y=b \times\left[1-e^{-c(t-L a g)}\right]$

where $y$ is the volume (mL/g DM) of GP at time $t(h) ; b$ is the asymptotic GP $(\mathrm{mL} / \mathrm{g} \mathrm{DM}) ; c$ is the fractional rate of fermentation $(/ \mathrm{h})$, and $\operatorname{Lag}(\mathrm{h})$ is the discrete lag time prior to any gas is released.

The experimental design for the in vitro ruminal gas, $\mathrm{CH}_{4}$ and $\mathrm{CO}_{2}$ productions, and fermentation parameters analysis was a completely random design considering, as fixed factors, additive types (A) and additive doses (D) in the linear model (Steel et al., 1997). Data of each of the three runs within the same sample were averaged prior to statistical analysis. Mean values of each individual extract within each species (three samples of each) were used as the experimental unit. The statistical model was:

$Y_{j k l}=\mu+A_{j}+D_{k}+(A \times D)_{j k}+E_{j k l}$

where: $Y_{j k l}=$ is every observation of the $j$ th feed additive $\left(A_{j}\right)$ when incubated in the $k$ th additive doses $\left(D_{k}\right) ; \mu$ is the general mean; and $E_{j k l}$ is experimental error. Linear and quadratic polynomial contrasts were used to examine responses to increasing levels of additives.

\section{Results and discussion}

\subsection{Gas production and fermentation}

Extents ' $b$ ' and rate of GP were similar among different treatment at different levels; however, the rate of digestion was highest $(P<0.05)$ at $120 \mu \mathrm{L}$ garlic oil and intermediate in all other treatments (Table 1$)$. The in vitro rumen GP $(\mathrm{mL} / \mathrm{g}$ incubated $\mathrm{DM})$ as affected by the different feed additives are shown in Fig. 1. Fermentation is generally index with degradation yielding short chain fatty acids and various gases, principally $\mathrm{CO}_{2}, \mathrm{H}_{2}, \mathrm{CH}_{4}$, and nitrous oxide; some of which are affected by other substances including organic acids (Elghandour et al., 2016a), exogenous fibrolytic enzymes (Elghandour et al., 2016b; Kholif et al., 2016), yeast cell (Elghandour et al., 2016c,d; Velazquez et al., 2016).

Table 1

Effect of different feed additives on in vitro rumen gas kinetics of a high concentrate diet fed to young calves at 60 days of age.

\begin{tabular}{|c|c|c|c|c|c|c|}
\hline \multirow[t]{2}{*}{ Additive type } & \multirow[t]{2}{*}{ Dose (/g DM) } & \multicolumn{3}{|c|}{$\begin{array}{l}\text { Gas production }(\mathrm{mL} / \mathrm{g} \\
\mathrm{DM})^{\mathrm{a}}\end{array}$} & \multicolumn{2}{|c|}{$\begin{array}{l}\text { Fermentation } \\
\text { kinetics }\end{array}$} \\
\hline & & $b$ & $c$ & Lag & $\mathrm{pH}$ & $\mathrm{DMD}^{\mathrm{b}}$ \\
\hline Control & No additive & 382.9 & $0.058 \mathrm{ab}$ & $2.69 \mathrm{~b}$ & 6.9 & $693.3 a$ \\
\hline \multirow[t]{4}{*}{ Garlic oil } & $30 \mu \mathrm{L}$ & 404.1 & $0.057 \mathrm{~b}$ & $2.72 b$ & 7.0 & $671.1 \mathrm{a}$ \\
\hline & $120 \mu \mathrm{L}$ & 283.4 & $0.108 \mathrm{a}$ & 6.33ab & 6.8 & $684.9 a$ \\
\hline & $250 \mu \mathrm{L}$ & 372 & $0.085 a b$ & $8.94 a$ & 5.8 & 615.3ab \\
\hline & $500 \mu \mathrm{L}$ & 213 & $0.067 \mathrm{ab}$ & $6.45 \mathrm{ab}$ & 7.0 & $554.1 \mathrm{~b}$ \\
\hline \multirow[t]{2}{*}{ Xylanase } & $3 \mu \mathrm{L}$ & 350.5 & $0.068 \mathrm{ab}$ & $2.78 b$ & 6.9 & 701.1a \\
\hline & $6 \mu \mathrm{L}$ & 354 & $0.077 \mathrm{ab}$ & $3.14 \mathrm{~b}$ & 6.9 & $689.8 a$ \\
\hline \multirow[t]{2}{*}{ Yeast } & $2 \mathrm{mg}$ & 345.2 & $0.069 \mathrm{ab}$ & $2.92 \mathrm{~b}$ & 6.9 & $698.6 a$ \\
\hline & $4 \mathrm{mg}$ & 347.5 & $0.063 \mathrm{ab}$ & $2.44 \mathrm{~b}$ & 6.9 & $695.1 \mathrm{a}$ \\
\hline Pooled SEM ${ }^{\mathrm{c}}$ & & 74.61 & 0.0192 & 1.699 & 0.62 & 34.4 \\
\hline Additive effect & & 0.794 & 0.847 & 1.000 & 0.992 & 0.713 \\
\hline \multicolumn{7}{|l|}{ Dose effect } \\
\hline Linear & & 0.718 & 0.073 & $<0.001$ & 0.022 & 0.005 \\
\hline Quadratic & & 0.051 & 0.008 & 0.520 & 0.254 & 0.191 \\
\hline Additive $\times$ Dose & & 0.5021 & 0.569 & 0.975 & 0.899 & 0.416 \\
\hline
\end{tabular}

Means in the same column with different superscripts differ $(P<0.05)$.

${ }^{a} b$ is the asymptotic gas production $(\mathrm{mL} / \mathrm{g} \mathrm{DM}) ; c$ is the rate of gas production

(/h); Lag is the initial delay before gas production begins $(\mathrm{h})$

b DMD is dry matter degradability.

c SEM is standard error of the mean.
However, xylanase enzyme was expected to increase degradation and GP rate (Elghandour et al., 2016b; Kholif et al., 2016) but was not limiting fermentation in the rumen. Yeast cells consume $\mathrm{O}_{2}$ molecules making the environment commensurate for optimum activity of various organisms (Newbold et al., 1996). The current study confirmed the lack of effect due to levels of yeast (Velazquez et al., 2016) but disagrees with others (Elghandour et al., 2016c,d) who report improved GP, suggesting that yeast can sometime but not always increase GP. These feed additives tended to exert a quadratic decrease in maximum GP. Garlic oil linearly delayed $(P<0.001)$ the onset of fermentation relative to xylanase, yeast and the control, suggesting that substances that directly affect the general population of rumen micro-organisms would generally delay the onset of fermentation.

The fermentation $\mathrm{pH}$ was affected linearly $(P=0.022)$ with different additives (Table 1 ). Garlic oil linearly decreased in vitro digestibility of DM $(P<0.05)$, while there was no difference between levels of either xylanase or level of yeast. Moreover, garlic oil $(P<0.01)$ decreased DMD, while xylanase and yeast had no effect. The linear decrease in the $\mathrm{pH}$ with increasing garlic oil level was unexpected since DM degradation decreased linearly with increasing additives, but these relationships are difficult to explain in fermentation terms. It was expected garlic oil would reduce the activity of all rumen micro-organism (bacteria, fungi and protozoa), therefore, a decrease in DM degradation in the current study agrees with the anti-microbial effects in various reports (MirzaeiAghsaghali et al., 2012).

\subsection{Effect of additives on $\mathrm{CH}_{4}$ production}

Fig. 2 shows the in vitro rumen $\mathrm{CH}_{4}$ production $(\mathrm{mL} / \mathrm{g}$ incubated DM) as affected by the different feed additives. The effect of additive $\times$ dose interaction was significant $(P<0.05)$ during all hours of incubation (Table 2$)$. The control produced most $(P<0.05)$ $\mathrm{CH}_{4}$ (expressed as: $\mathrm{mL} / \mathrm{g}$ DM incubated, and $\mathrm{mL} / \mathrm{g}$ degraded $\mathrm{DM}$ ) followed in decreasing order by xylanase, yeast and garlic oil. These effects were rather amplified when $\mathrm{CH}_{4}$ production was expressed as a proportion of total GP. It is accepted that the production of $\mathrm{H}_{2}$ in the rumen limits the fermentation of fiber, and reduces digestibility; however, a copious quantity of $\mathrm{H}_{2}$ is produced and together with $\mathrm{CO}_{2}$ is used to synthesize $\mathrm{CH}_{4}$ by methanogenic microorganisms. This process of $\mathrm{CH}_{4}$ production uses reduced cofactors liberating oxidized ones, helping rumen microbes to recycle these co-factors. Although in agreement with Kholif et al. (2016), it is surprising that the control treatment yielded the highest amount of $\mathrm{CH}_{4}$, followed by yeast and xylanase (Table 2). It is not clear why xylanase would depress $\mathrm{CH}_{4}$ production when this supplementary enzyme is supposed to increase the availability of hemicellulose and $\mathrm{CH}_{4}$ production (Elghandour et al., 2016b). Unless the digestion of hemicellulose liberates lignin compounds, increasing the chance of attachment to microorganisms or with microbial products forming antibiotic or bacteriostatic metabolite, as such having little or no effect on digestion as indicated in this study.

It is known that yeast products increase nutrient digestibility (Hassan et al., 2016) specifically by elevating populations of cellulolytic and amylolytic bacteria in the rumen accompanied by altered fatty acid production (Kumar et al., 1997). Some live $S$. cerevisiae added in very small amounts have been reported to reduce methanogenesis in the rumen (Hristov et al., 2013). In other studies, yeast supplementation had no impact on $\mathrm{CH}_{4}$ production (McGinn et al., 2004). In addition, studies on yeasts appear somewhat conflicting, suggesting either an increase in $\mathrm{CH}_{4}$ production (Elghandour et al., 2016c,d) or no effect (Opsi et al., 2011) in batch cultures with mixed rumen microflora; in agreement with the 

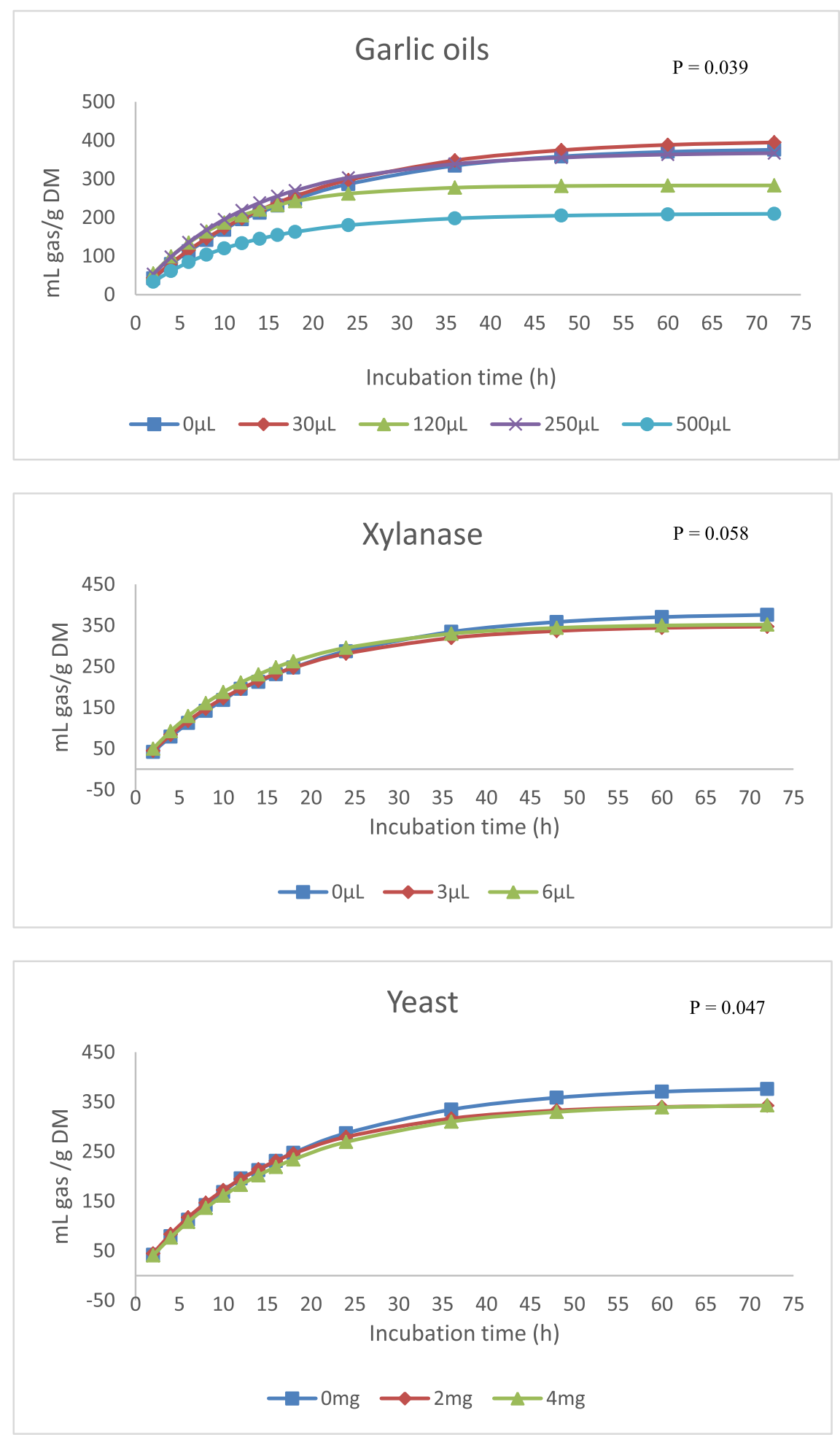

Fig. 1. In vitro rumen gas production ( $\mathrm{mL} / \mathrm{g}$ incubated $\mathrm{DM}$ ) of a high concentrate diet fed to young calves at 60 days of age incubated with no additive, garlic oil, xylanase, and yeast.

observations in the current study. It was expected that yeast cultures would stimulate acetogens to compete or to co-metabolize $\mathrm{H}_{2}$ with methanogens and reduce $\mathrm{CH}_{4}$ emissions (Hristov et al., 2013) and/or scavenge $\mathrm{O}_{2}$ and make the environment more conducive for fermentation and microbial growth. Implying a tendency of decreased $\mathrm{CH}_{4}$ production with yeast was expected in the study. Thus, in a few studies, feeding live yeast products have consistently reduced $\mathrm{CH}_{4}$ production by $20-58 \%$ (Lynch and Martin, 2002; Newbold and Rode, 2006) but it remains uncertain whether a 60day old rumen environment could be less responsive to yeast.

Garlic oil has been shown to have both Gram negative and Gram positive anti-bacteria properties largely due to allicin (allyl 2propene thiosulfinate) (Cavallito and Bailey, 1944), anti-fungi (Adetumbi et al., 1986) and anti-viruses (Weber et al., 1992) 

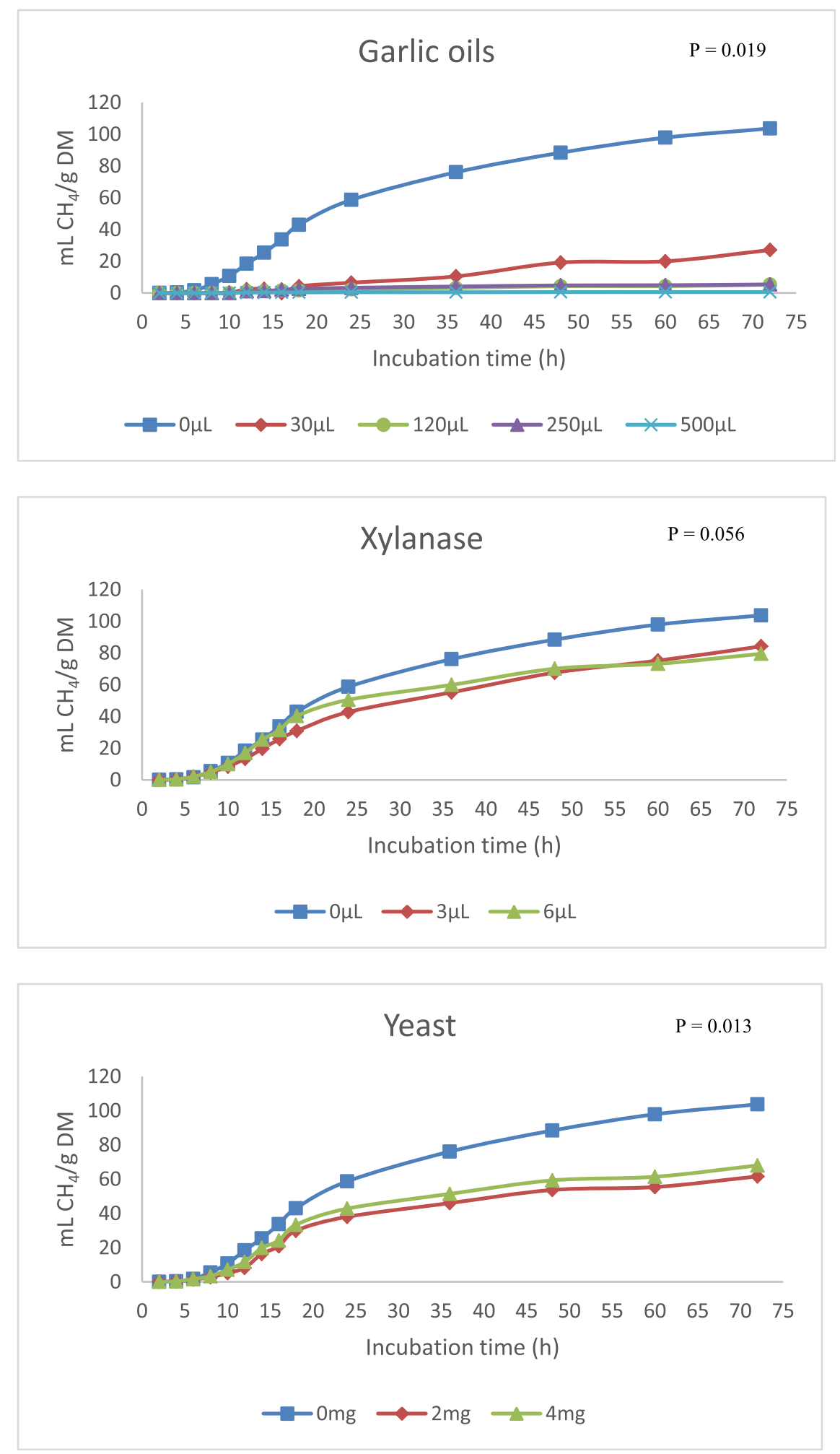

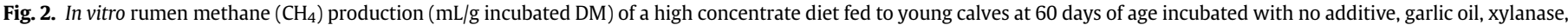
and yeast.

properties. Based on these properties, others have either defined the minimum inhibitory concentration (Nejad et al., 2014) or pointed to the antiparasite role (Goncagul and Ayaz, 2010) of this food item. In rumen fluid, $\mathrm{CH}_{4}$ producing organisms live in symbiotic relationship with cellulolytic organism, protozoa and fungi, the latter two relationships being involved in extensive production of $\mathrm{CH}_{4}$; methanogens also shift $\mathrm{H}_{2}$ among themselves (McAllister et al., 1994). Both linear and quadratic decreases in $\mathrm{CH}_{4}$ production due to increasing levels of garlic oil reported here may be related to any one of the following explanation. Garlic oil might 
Table 2

Effect of different feed additives on in vitro methane $\left(\mathrm{CH}_{4}\right)$ production of a high concentrate diet fed to young calves at 60 days of age.

\begin{tabular}{|c|c|c|c|c|c|c|c|c|c|c|c|c|c|}
\hline \multirow[t]{3}{*}{ Additive type } & \multirow[t]{3}{*}{ Dose (/g DM) } & \multicolumn{12}{|c|}{$\mathrm{CH}_{4}$ production } \\
\hline & & \multicolumn{4}{|c|}{$\mathrm{mL} / \mathrm{g}$ incubated $\mathrm{DM}$} & \multicolumn{4}{|c|}{$\mathrm{mL} / \mathrm{g}$ degraded $\mathrm{DM}$} & \multicolumn{4}{|c|}{ Proportional $\mathrm{CH}_{4}$ production } \\
\hline & & $6 \mathrm{~h}$ & $24 \mathrm{~h}$ & $48 \mathrm{~h}$ & $72 \mathrm{~h}$ & $6 \mathrm{~h}$ & $24 \mathrm{~h}$ & $48 \mathrm{~h}$ & $72 \mathrm{~h}$ & $6 \mathrm{~h}$ & $24 \mathrm{~h}$ & $48 \mathrm{~h}$ & $72 \mathrm{~h}$ \\
\hline Control & No additive & $1.71 \mathrm{a}$ & $58.7 a$ & $88.4 \mathrm{a}$ & $103.7 \mathrm{a}$ & $2.47 a$ & $84.9 \mathrm{a}$ & $127.7 \mathrm{a}$ & 149.6a & $1.53 a$ & $20.55 a$ & $24.83 a$ & $27.81 \mathrm{a}$ \\
\hline \multirow[t]{4}{*}{ Garlic oil } & $30 \mu \mathrm{L}$ & $0.00 \mathrm{~b}$ & $6.5 c$ & $19.2 \mathrm{~d}$ & $27.1 \mathrm{bc}$ & $0.00 \mathrm{~b}$ & $9.6 \mathrm{~b}$ & $28.5 c$ & $40.3 \mathrm{bc}$ & $0.00 \mathrm{~b}$ & $2.17 b$ & $5.00 \mathrm{~b}$ & $6.67 \mathrm{bc}$ \\
\hline & $120 \mu \mathrm{L}$ & $0.00 \mathrm{~b}$ & $2.2 \mathrm{c}$ & $4.3 d$ & $5.3 c$ & $0.00 \mathrm{~b}$ & $3.3 \mathrm{~b}$ & $6.2 \mathrm{c}$ & $7.0 \mathrm{c}$ & $0.00 \mathrm{~b}$ & $0.83 b$ & $1.50 \mathrm{~b}$ & $1.83 c$ \\
\hline & $250 \mu \mathrm{L}$ & $0.00 \mathrm{~b}$ & $3.3 c$ & $4.8 \mathrm{~d}$ & $5.4 \mathrm{c}$ & $0.00 \mathrm{~b}$ & $5.4 \mathrm{~b}$ & $7.6 c$ & $8.6 c$ & $0.00 \mathrm{~b}$ & $1.17 \mathrm{~b}$ & $1.50 \mathrm{~b}$ & $1.67 \mathrm{c}$ \\
\hline & $500 \mu \mathrm{L}$ & $0.00 \mathrm{~b}$ & $0.5 c$ & $0.6 \mathrm{~d}$ & $0.6 c$ & $0.00 \mathrm{~b}$ & $0.9 \mathrm{~b}$ & $1.0 \mathrm{c}$ & $1.1 \mathrm{c}$ & $0.00 \mathrm{~b}$ & $0.50 \mathrm{~b}$ & $0.50 \mathrm{~b}$ & $0.50 c$ \\
\hline \multirow[t]{2}{*}{ Xylanase } & $3 \mu \mathrm{L}$ & $2.04 a$ & 42.8ab & 67.6ab & $84.2 \mathrm{a}$ & $2.92 a$ & 61.1a & $96.5 \mathrm{ab}$ & $120.2 \mathrm{a}$ & $1.70 \mathrm{a}$ & $15.08 \mathrm{a}$ & $20.08 a$ & $24.28 \mathrm{a}$ \\
\hline & $6 \mu \mathrm{L}$ & $2.14 a$ & $50.5 \mathrm{ab}$ & 70.1ab & 79.5a & $3.11 \mathrm{a}$ & $73.4 \mathrm{a}$ & 102.0ab & $115.7 a$ & $1.67 \mathrm{a}$ & 17.09a & $20.22 \mathrm{a}$ & $22.39 a$ \\
\hline \multirow[t]{2}{*}{ Yeast } & $2 \mathrm{mg}$ & $1.39 a$ & $38.0 \mathrm{~b}$ & $53.7 b c$ & 61.6ab & $2.00 a$ & $54.5 b$ & $76.9 \mathrm{~b}$ & $88.2 \mathrm{ab}$ & $1.19 \mathrm{a}$ & $13.53 a$ & $16.11 a$ & 17.93ab \\
\hline & $4 \mathrm{mg}$ & $1.66 a$ & 42.8ab & 59.3ab & 68.0ab & $2.39 a$ & $61.7 b$ & 85.4ab & 97.9ab & $1.54 \mathrm{a}$ & $15.92 \mathrm{a}$ & $18.01 \mathrm{a}$ & $19.86 a$ \\
\hline Pooled SEM ${ }^{\mathrm{a}}$ & & 0.440 & 7.79 & 11.69 & 16.76 & 0.669 & 12.39 & 18.01 & 24.87 & 0.371 & 2.886 & 3.444 & 4.693 \\
\hline Additive effect & & 0.001 & 0.001 & 0.003 & 0.015 & 0.002 & 0.003 & 0.006 & 0.020 & 0.001 & 0.001 & 0.002 & 0.006 \\
\hline \multicolumn{14}{|l|}{ Dose effect } \\
\hline Linear & & 0.101 & 0.176 & 0.043 & 0.045 & $<0.001$ & $<0.001$ & $<0.001$ & $<0.001$ & $<0.001$ & $<0.001$ & $<0.001$ & $<0.001$ \\
\hline Quadratic & & 0.001 & 0.031 & 0.203 & 0.229 & 0.009 & $<0.001$ & $<0.001$ & 0.001 & 0.004 & $<0.001$ & $<0.001$ & 0.001 \\
\hline Additive $\times$ Dose & & 0.001 & 0.001 & 0.001 & 0.004 & 0.001 & 0.001 & 0.002 & 0.006 & 0.001 & 0.001 & 0.001 & 0.002 \\
\hline
\end{tabular}

Means in the same column with different superscripts differ $(P<0.05)$.

a SEM standard error of the mean.

suppressed the activity of all organisms in the rumen with increasing concentration thus delaying colonization, decreasing digestion, and reducing the population of protozoa (Harris et al., 2001) and methanogens.

\subsection{Effect of additives on $\mathrm{CO}_{2}$ production}

Fig. 3 shows the in vitro rumen $\mathrm{CO}_{2}$ production $(\mathrm{mL} / \mathrm{g}$ incubated $D M)$ as affected by the different feed additives. The effect additive $\times$ dose interaction was significant (at least at $P<0.04$ ) during all hours of incubation (Table 3 ). The control produced more $(P<0.05) \mathrm{CO}_{2}$ (expressed as: $\mathrm{mL} / \mathrm{g} \mathrm{DM}$ incubated, $\mathrm{mL} / \mathrm{g}$ degraded $\mathrm{DM}$, and as a proportion of total GP) than any other treatment. Consequently, the yield of $\mathrm{CO}_{2}$ was highest $(P<0.001)$ in the controlled followed in decreasing order by xylanase, yeast and garlic oil. Within each additive, $\mathrm{CO}_{2}$ production increased linearly with xylanase and yeast levels $(P<0.001)$ but decreased linearly $(P<0.001)$ and in a quadratic fashion $(P<0.001)$ with increasing level of garlic oil. Carbon dioxide in the most produced gas in rumen fermentation during metabolism of pyruvic acid in the production of acetic acid. Throughout the incubation period the control treatment yielded significantly more $\mathrm{CO}_{2}$ than any of these feed additives in agreement with Kholif et al. (2016) for reasons advanced below. Xylanase is viewed simply as an enzyme that hydrolyses hemicellulose to xylose before further fermentation can take place. However, it is a xylan-degrading enzyme system which includes the main-chain-cleaving enzymes, endo-b-1,4-xylanases and b-xylosidases, and the side-chain enzyme activities, acetylxylan esterases, a-glucuronidases, ferulic acid esterases and a-arabinofur- anosidases (Coughlan et al., 1993). Therefore, in the process of fermentation or digesting of hemicellulose, some of its metabolites and intermediates of lignin might react forming products that slows or reduce microbial activity. In some situations, addition of lignin compounds (vanillic acid, protocatechuic acid, acetovanillone, and vanillin) increased the rate of hydrolysis of xylan probably changing the structure of xylanase (Kaya et al., 2000); therefore, it is possible some other substances would have a negative effect. Since xylanase is sometimes none-limiting in the rumen fluid there is generally little to high changes in digestion following xylanase supplementation (Elghandour et al., 2016b). A tendency of decreased $\mathrm{CO}_{2}$ production with increasing level of xylanase as demonstrated in this study was observed suggesting that xylanase enzyme may help to increase sugars for the survival of propionate-producing microorganisms.

Live yeast cells naturally scavenge for $\mathrm{O}_{2}$ and produce $\mathrm{CO}_{2}$ in the rumen, thus increasing rumen anaerobiosis and microbial viability. That is why most groups of rumen microbes that do not compete for a common substrate (glucose) would tend to increase in the presence of live yeast cells. An increase in the population of fibrolytic organisms was expected to increase the rate of fiber digestion; this process majors in the production of acetate and $\mathrm{CO}_{2}$ in the rumen. Naturally, it was expected that more $\mathrm{CO}_{2}$ would be produced with this feed additive but the results showed an opposite trend from the control treatment. It is speculated that yeast in these feed additive produced anti-microbial metabolites that tended to affect digestion adversely. That is why the control treatment produced more $\mathrm{CO}_{2}$ at all incubation times that yeast treatments. Yeast is known to shift $\mathrm{H}_{2}$ utilization from methanogenesis to reductive acetogenesis through the homoacetogenic bacteria that produces acetate from $\mathrm{CO}_{2}$ and $\mathrm{H}_{2}$ (Mwenya et al., 2004), even in the presence of methanogens (Chaucheyras-Durand et al., 1997), thus helping to explain a tendency for yeast to decrease $\mathrm{CO}_{2}$ emission.

Consequently, both $\mathrm{CO}_{2}$ and $\mathrm{CH}_{4}$ production would reduce as observed in this study, where $\mathrm{CH}_{4}$ production was highest in the control treatment and lowest in the intermediate garlic treatment, suggesting that $250 \mu \mathrm{l}$ of garlic oil might be the level at which the least $\mathrm{CH}_{4}$ would be produced.

\section{Future outlook}

The research area of including natural feed additives in ruminant nutrition has gained the attention of researchers to improve feed utilization, animal productivity and reduce GHG emission. However, studies dealing with dairy calves are still relatively scare, with almost no study on GHG emission. The tested feed additives showed promising results to reduce $\mathrm{CH}_{4}$ and $\mathrm{CO}_{2}$ production in the in vitro scale. However, further research is warranted to establish the efficacy of such feed additives in in vivo trials.

\section{Conclusions}

Garlic oil, yeast, and xylanase at different levels did not affect the extents of GP; however, garlic oil increased the rate of digestion and the lag phase. Besides, garlic oil decreased $\mathrm{CH}_{4}$ and $\mathrm{CO}_{2}$ 



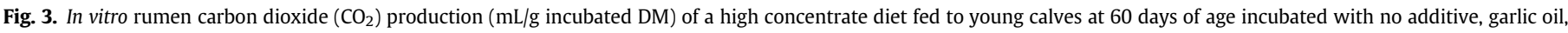
xylanase, and yeast. 
Table 3

Effect of different feed additives on in vitro carbon dioxide $\left(\mathrm{CO}_{2}\right)$ production of a high concentrate diet fed to young calves at 60 days of age.

\begin{tabular}{|c|c|c|c|c|c|c|c|c|c|c|c|c|c|}
\hline \multirow[t]{3}{*}{ Additive type } & \multirow[t]{3}{*}{ Dose (/g DM) } & \multicolumn{12}{|c|}{$\mathrm{CO}_{2}$ production } \\
\hline & & \multicolumn{4}{|c|}{$\mathrm{mL} / \mathrm{g}$ incubated $\mathrm{DM}$} & \multicolumn{4}{|c|}{$\mathrm{mL} / \mathrm{g}$ degraded $\mathrm{DM}$} & \multicolumn{4}{|c|}{ Proportional $\mathrm{CO}_{2}$ production } \\
\hline & & $6 \mathrm{~h}$ & $24 \mathrm{~h}$ & $48 \mathrm{~h}$ & $72 \mathrm{~h}$ & $6 \mathrm{~h}$ & $24 \mathrm{~h}$ & $48 \mathrm{~h}$ & $72 \mathrm{~h}$ & $6 \mathrm{~h}$ & $24 \mathrm{~h}$ & $48 \mathrm{~h}$ & $72 \mathrm{~h}$ \\
\hline Control & No additive & $0.00 \mathrm{~d}$ & $2.4 \mathrm{bc}$ & $4.5 \mathrm{bc}$ & $6.0 \mathrm{bc}$ & $0.00 \mathrm{~d}$ & $3.42 \mathrm{~cd}$ & $6.47 \mathrm{bc}$ & $8.57 b c$ & $0.00 \mathrm{c}$ & $0.83 c$ & $1.27 \mathrm{bc}$ & $1.60 \mathrm{abc}$ \\
\hline \multirow[t]{4}{*}{ Garlic oil } & $30 \mu \mathrm{L}$ & $0.42 \mathrm{a}$ & $10.0 \mathrm{a}$ & $15.3 a$ & $18.4 \mathrm{a}$ & $0.62 \mathrm{a}$ & $14.77 \mathrm{a}$ & $22.60 a$ & $27.40 a$ & $0.36 a$ & $3.33 a$ & $4.05 a$ & $4.64 a$ \\
\hline & $120 \mu \mathrm{L}$ & $0.23 a b c$ & $6.9 \mathrm{ab}$ & $9.7 \mathrm{abc}$ & $11.1 \mathrm{abc}$ & $0.37 b$ & 10.10abc & 14.16abc & $16.28 \mathrm{abc}$ & $0.19 b$ & $2.62 \mathrm{ab}$ & 3.42ab & $3.91 \mathrm{ab}$ \\
\hline & $250 \mu \mathrm{L}$ & $0.16 \mathrm{bcd}$ & 7.9a & 12.0ab & $14.2 \mathrm{ab}$ & $0.25 b c$ & $12.77 \mathrm{ab}$ & 19.50ab & $23.11 \mathrm{ab}$ & $0.12 b c$ & $2.67 a b$ & 3.45ab & $3.96 a$ \\
\hline & $500 \mu \mathrm{L}$ & $0.07 \mathrm{~cd}$ & $2.7 \mathrm{bc}$ & $4.3 b c$ & $5.2 \mathrm{bc}$ & $0.13 \mathrm{~cd}$ & $4.96 \mathrm{bcd}$ & $8.01 b c$ & $9.75 \mathrm{abc}$ & $0.09 \mathrm{bc}$ & $1.19 b c$ & $1.65 \mathrm{abc}$ & $1.60 \mathrm{abc}$ \\
\hline \multirow[t]{2}{*}{ Xylanase } & $3 \mu \mathrm{L}$ & $0.00 \mathrm{~d}$ & $1.3 \mathrm{c}$ & $2.2 \mathrm{c}$ & $3.5 b c$ & $0.00 \mathrm{~d}$ & $3.09 \mathrm{~cd}$ & $6.25 b c$ & $9.07 \mathrm{bc}$ & $0.00 c$ & $0.77 \mathrm{c}$ & $1.27 b c$ & 1.76abc \\
\hline & $6 \mu \mathrm{L}$ & $0.00 \mathrm{~d}$ & $1.7 \mathrm{c}$ & $2.7 \mathrm{c}$ & $3.3 \mathrm{bc}$ & $0.00 \mathrm{~d}$ & $2.02 \mathrm{~d}$ & $3.62 c$ & $4.80 c$ & $0.00 c$ & $0.47 c$ & $0.70 c$ & $0.90 \mathrm{c}$ \\
\hline \multirow[t]{2}{*}{ Yeast } & $2 \mathrm{mg}$ & $0.00 \mathrm{~d}$ & $1.2 \mathrm{c}$ & $1.9 \mathrm{c}$ & $2.4 \mathrm{c}$ & $0.00 \mathrm{~d}$ & $1.89 \mathrm{~d}$ & $2.68 c$ & $3.58 \mathrm{c}$ & $0.00 \mathrm{c}$ & $0.47 c$ & $0.57 c$ & $0.73 c$ \\
\hline & $4 \mathrm{mg}$ & $0.00 \mathrm{~d}$ & $1.2 \mathrm{c}$ & $1.8 \mathrm{c}$ & $2.3 \mathrm{c}$ & $0.00 \mathrm{~d}$ & $1.81 \mathrm{~d}$ & $2.70 \mathrm{c}$ & $3.32 \mathrm{c}$ & $0.00 c$ & $0.47 c$ & $0.57 c$ & $0.67 c$ \\
\hline Pooled SEM ${ }^{\mathrm{a}}$ & & 0.075 & 1.97 & 3.26 & 4.33 & 0.085 & 3.024 & 5.264 & 6.861 & 0.044 & 0.655 & 0.931 & 1.158 \\
\hline Additive effect & & $<0.001$ & 0.001 & 0.004 & 0.011 & $<0.001$ & 0.005 & 0.024 & 0.058 & $<0.001$ & 0.004 & 0.031 & 0.082 \\
\hline \multicolumn{14}{|l|}{ Dose effect } \\
\hline Linear & & 0.011 & 0.033 & 0.052 & 0.085 & 0.001 & 0.001 & 0.003 & 0.009 & 0.002 & 0.001 & 0.004 & 0.012 \\
\hline Quadratic & & 0.494 & 0.046 & 0.031 & 0.041 & 0.001 & 0.312 & 0.731 & 0.920 & $<0.001$ & 0.049 & 0.088 & 0.144 \\
\hline Additive $\times$ Dose & & $<0.001$ & 0.001 & 0.001 & 0.003 & $<0.001$ & 0.001 & 0.007 & 0.018 & $<0.001$ & 0.001 & 0.009 & 0.027 \\
\hline
\end{tabular}

Means in the same column with different superscripts differ $(P<0.05)$.

a SEM standard error of the mean.

productions, followed by yeast and xylanase. It can be concluded that garlic oil followed by yeast and then xylanase can be used to mitigate in vitro $\mathrm{CH}_{4}$ and $\mathrm{CO}_{2}$ production from dairy calves fed a high concentrate diet. However, further research is warranted to establish the efficacy of such feed additives in in vivo trials.

\section{Acknowledgement}

The authors acknowledge the financial support from the IAEA Vienna, Austria, research contract number MEX16307 within the D3.10.27 Coordinated Research Project. First author would like the thankful the Mexican National Council for Science and Technology (CONACyT, Mexico) for the M.Sc scholarship received. Kholif, A.E. thanks the CONACyT and The World Academy of Sciences (TWAS, Italy) for supporting his postdoctoral fellowship at the Facultad de Medicina Veterinaria y Zootecnia, Universidad Autónoma del Estado de México.

\section{References}

Adetumbi, M., Javor, G.T., Lau, B.H.S., 1986. Allium sativum (Garlic) inhibits lipid synthesis by Candida albicans. Antimicrob. Agents Chemother. 30, 499-501.

Alsersy, H., Salem, A.Z.M., Borhami, B.E., Olivares, J., Gado, H.M., Mariezcurrena, M.D., Yacuot, M.H., Kholif, A.E., El-Adawy, M., Hernandez, S.R., 2015. Effect of Mediterranean saltbush (Atriplex halimus) ensilaging with two developed enzyme cocktails on feed intake, nutrient digestibility and ruminal fermentation in sheep. Anim. Sci. J. 86, 51-58.

AOAC, 1997. Association of Official Analytical Chemists. Official Methods of Analysis, sixteenth ed. AOAC, Arlington, VA, USA.

Busquet, M., Calsamiglia, S., Ferret, A., Cardozo, P.W., Kamel, C., 2005. Effects of cinnamaldehyde and garlic oil on rumen microbial fermentation in a dual flow continuous culture. J. Dairy Sci. 88, 2508-2516.

Cavallito, C.J., Bailey, J.H., 1944. Allicin, the antibacterial principle of Allium sativum. I. Isolation, physical properties, and antibacterial action. J. Am. Chem. Soc. 66, 1950.

Cedillo, J., Kholif, A.E., Salem, A.Z.M., Elghandour, M.M.Y., Vázquez, J.F., Alonso, M.U., Barbabosa, A. Chagoyán, J.C.V. Reyna, A.G. 2015. Oral administration of Sauce llorón extract to growing lambs to control gastrointestinal nematodes and Moniezia spp. Asian Pac. J. Trop. Med. 8 (7), 520-525.

Chaucheyras-Durand, F, Fonty, G, Bertin, G, 1997. Effects of a microbial additive, Levucell SC, on growth and metabolism of a ruminal acetogenic bacterial strain in vitro. In: Proceedings of Rumen Function Conference, Chicago, USA, p. 33.

Coughlan, M.P., Tuohy, M.G., Filho, E.X.F., Puls, J., Claeyssens, M., Vrsanskaa, M. Hughes, M.M., 1993. Enzymological aspects of microbial hemicellulases with emphasis on fungal systems. In: Coughlan, M.P., Hazlewood, G.P. (Eds.), Hemicellulose and Hemicellulases. Portland Press, London, pp. 53-84. ISBN 185578 0364.

Elghandour, M.M.Y., Kholif, A.E., Hernandez, J., Mariezcurrena, M.D., Lopez, S., Camacho, L.M., Marquez, O., Salem, A.Z.M., 2016b. Influence of the addition of exogenous xylanase with or without pre-incubation on the in vitro rumina fermentation of three fibrous feeds. Czech. J. Anim. Sci. 61, 262-272.

Elghandour, M.M.Y., Kholif, A.E., Lopez, S., Mendoza, G.D., Odongo, N., Salem, A.Z.M. 2016c. In vitro gas, methane, and carbon dioxide production of high fibrous diets incubated with fecal inocula from horses in response to the supplementation with different live yeast additives. J. Equine Vet. Sci. 38, 67-71.

Elghandour, M.M.Y., Kholif, A.E., Salem, A.Z.M., de Oca, R.M., Barbabosa, A., Mariezcurrena, M.D., Olfadehan, O.A., 2016a. Addressing sustainable ruminal methane and carbon dioxide emissions of soybean hulls by organic acid salts. J. Clean. Prod. 135, 194-200.

Elghandour, M.M.Y., Salem, A.Z.M., Martínez Castañeda, J.S., Camacho, L.M., Kholif, A.E., Vazquez, J.C., 2015. Direct-fed microbes: a tool for improving the utilization of low quality roughages in ruminants. J. Integr. Agr. 14 (3), 526-533.

Elghandour, M.M.Y., Vazquez, J.C., Salem, A.Z.M., Kholif, A.E., Capriano, M.M., Camacho, L.M., Marquez, O., 2016d. In vitro gas and methane production of two mixed rations influenced by three different cultures of Saccharomyces cerevisiae. J. Appl. Anim. Res. http://dx.doi.org/10.1080/09712119.2016.1204304.

France, J., Dijkstra, J., Dhanoa, M.S., López, S., Bannink, A., 2000. Estimating the extent of degradation of ruminant feeds from a description of their gas production profiles observed in vitro: derivation of models and other mathematical considerations. Br. J. Nutr. 83, 143-150.

Gebhardt, R., Beck, H., 1996. Differential inhibitory effects of garlic-derived organosulfur compounds on cholesterol biosynthesis in primary rat hepatocyte cultures. Lipids 31, 1269-1276.

Goering, M.K., Van Soest, P.J., 1970. Forage Fibre Analysis (Apparatus, Reagents, Procedures and Some Applications). Agricultural Research Service, USDA, Washington, DC.

Goncagul, G., Ayaz, E., 2010. Antimicrobial effects of garlic (Allium sativum) and traditional medicine. J. Anim. Vet. Adv. 9 (1), 1-4.

Harris, J.C., Cottrel, S.L., Plummer, S., Lloyd, D., 2001. Antimicrobial properties of allium sativum (garlic). Appl. Microbil. Biotechnol. 57, 282-286.

Hassan, A.A., Salem, A.Z.M., Kholif, A.E., Samir, M., Yacout, M.H., Abu Hafsa, S.H., Mendoza, G.D., Elghandour, M.M.Y., Ayala, M., Lopez, S., 2016. Performance of crossbred dairy Friesian calves fed two levels of Saccharomyces cerevisiae: intake, digestion, ruminal fermentation, blood parameters and faecal pathogenic bacteria. J. Agric. Sci. 154, 1488-1498.

Hristov, A.N., Oh, J., Firkins, J.L., Dijkstra, J., Kebreab, E., Waghorn, G., Makkar, H.P., Adesogan, A.T., Yang, W. Lee, C., Gerber, PJ., Henderson, B., Tricarico, J.M., 2013. Special topics: mitigation of methane and nitrous oxide emissions from animal operations: I. A review of enteric methane mitigation options. J. Anim. Sci. 91, 5045-5069.

Kaya, F., Heitmann Jr., J.A., Joyce, T.W., 2000. Influence of lignin and its degradation products on enzymatic hydrolysis of xylan. J. Biotech. 80, 241-247.

Kholif, A.E., Baza-García, L.A., Elghandour, M.M.Y., Salem, A.Z.M., Barbabosa, A. Dominguez-Vara, I.A., Sanchez-Torres, J.E., 2016. In vitro assessment of fecal inocula from horses fed on high-fiber diets with fibrolytic enzymes addition on gas, methane, and carbon dioxide productions as indicators of hindgut activity. J. Equine Vet. Sci. 39, 44-50.

Kumar, U., Sareen, V.K., Singh, S., 1997. Effect of yeast culture supplement on ruminal microbial populations and metabolism in buffalo calves fed a high roughage diet. J. Sci. Food Agric. 73, 231-236.

Lawson, L.D., 1996. The composition and chemistry of garlic cloves and processed garlic. In: Koch, H.P., Lawson, L.D. (Eds.), Garlic: the Science and Therapeutic Application of Allium Sativum L. And Related Species. Williams and Wilkins, Boltimore, pp. 37-108.

Lynch, H.A., Martin, S.A., 2002. Effects of Saccharomyces cerevisiae culture and Saccharomyces cerevisiae live cells on in vitro mixed ruminal microorganism 
fermentation. J. Dairy Sci. 85, 2603-2608.

McAllister, T.A., Okine, E.K., Mathison, G.W., Cheng, K.J., 1994. Dietary, environmental and microbiological aspects of methane production in ruminants. Can. J. Anim. Sci. 72, 231-243.

McGinn, S.M., Beauchemin, K.A., Coates, T., Colombatto, D., 2004. Methane emissions from beef cattle: effects of monensin, sunflower oil, enzymes, yeast, and furmaric acid. J. Anim. Sci. 82, 3346-3356.

Mirzaei-Aghsaghali, A., Maheri-Sis, N., 2011. Factors affecting mitigation of methane emission from ruminants I: feeding strategies. Asian J. Anim. Vet. Adv. 6, 888-908.

Mirzaei-Aghsaghali, A., Syadati, S.A., Fathi, H., Rasouli, S., Sadaghian, M., Tarahomi, M., 2012. Garlic in ruminants feeding. Asian J. Biol. Sci. 5, 328-340.

Morgavi, D.P., Nsereko, V.L., Rode, L.M., Beauchemin, K.A., McAllister, M., Wang, Y., 2000. A Trichoderma feed enzyme preparation enhances adhesion of Fibrobacter succinogenes to complex substrates but not to pure cellulose. In: Proceedings of the 25th Conference on Rumen Function, Chicago, Illinois, US.

Morsy, T.A., Kholif, A.E., Kholif, S.M., Kholif, A.M., Sun, X., Salem, A.Z.M., 2016. Effects of two enzyme feed additives on digestion and milk production in lactating Egyptian buffaloes. Ann. Anim. Sci. 16 (1), 209-222.

Mwenya, B., Santoso, B., Sar, C., Gamo, Y., Kobayashi, T., Arai, I., Takahashi, J., 2004 Effects of including 1,4-galacto-oligosaccharides, lactic acid bacteria or yeast culture on methanogenesis as well as energy and nitrogen metabolism in sheep. Anim. Feed Sci. Technol. 115, 313-326.

Nejad, A.S.M., Shabani, S., Bayatt, M., Hosseini, S.E., 2014. Antibacterial effects of garlic aqueous extract on Staphylococcus aureus in Hamburger. J. Microbiol. 7, e13134.

Newbold, C.J., Rode, L.M., 2006. Dietary additives to control methanogenesis in the rumen. Int. Congr. Ser. 1293, 138-147.

Newbold, C.J., Wallace, R.J., McIntosh, F.M., 1996. Mode of action of the yeast Saccharomyces cerevisiae as a feed additive for ruminants. Br. J. Nutr. 76, 249-261.

NRC, 2001. Nutrient Requirement of Dairy Cattle. 7th Rev. National Academy Press, Washington, DC.

Opsi, F., Fortina, R., Tassone, S., Bodas, R., López, S., 2011. Effects of inactivated and live cells of Saccharomyces cerevisiae on in vitro ruminal fermentation of diets with different forage: concentrate ratio. J. Agr. Sci. 150, 271-283.

Patra, A.K., 2012. The use of live yeast products as microbial feed additives in ruminant nutrition. Asian J. Anim. Vet. Adv. 7, 366-375.

Polyorach, S., Wanapat, M., Cherdthong, A, 2014. Influence of yeast fermented cassava chip protein (YEFECAP) and roughage to concentrate ratio on ruminal fermentation and microorganisms using in vitro gas production technique. Asian Australas. J. Anim. Sci. 27, 36-45.

Rojo, R., Kholif, A.E., Salem, A.Z.M., Elghandour, M.M.Y., Odongo, N.E., de Oca, R.M., Rivero, N., Alonso, M.U., 2015. Influence of cellulase addition to dairy goat diets on digestion and fermentation, milk production and fatty acid content. J. Agr. Sci. 153, 1514-1523.

SAS, 2002. User's Guide: Statistics. Ver 9.0.SAS Institute, Cary, NC.

Slade, E.M., Riutta, T., Roslin, T., Tuomisto, H.L., 2016. The role of dung beetles in reducing greenhouse gas emissions from cattle farming. Sci. Rep. 6, 18140 http://dx.doi.org/10.1038/srep18140.

Steel, R.G.D., Torrie, J.H., Dickey, D.A., 1997. Principles and Procedures of Statistics: a Biometrical Approach. McGraw Hill, New York, NY.

Theodorou, M.K., Williams, B.A., Dhanoa, M.S., McAllan, A.B., France, J., 1994 A simple gas production method using a pressure transducer to determine the fermentation kinetics of ruminant feeds. Anim. Feed Sci. Technol. 48, 185-197.

Vallejo, L.H., Salem, A.Z.M., Kholif, A.E., Elghangour, M.M.Y., Fajardo, R.C., Rivero, N. Bastida, A.Z., Mariezcurrena, M.D., 2016. Influence of cellulase or xylanase on the in vitro rumen gas production and fermentation of corn stover. Indian J. Anim. Sci. 86 (1), 70-74.

Van Soest, P.J., Robertson, J.B., Lewis, B.A., 1991. Methods for dietary fibre, neutra dtergent fibre, and non-starch carbohydrates in relation to animal nutrition. J. Dairy Sci. 74, 3583e3597.

Velazquez, A.E., Kholif, A.E., Elghandour, M.M.Y., Salem, A.Z.M., Jimenez, R.M.O. Pliego, A.B., Odongo, N., Borquez, J.L., Cipriano, M., Olivares, J., 2016. Effect of partial replacement of steam rolled corn with soybean hulls or prickly pear cactus in the horse's diet in the presence of live Saccharomyces cerevisae on in vitro fecal gas production. J. Equine Vet. Sci. 42, 94-101.

Wang, Y., McAllister, T.A., Rode, L.M., Beauchemin, K.A., Morgavi, D.P., Nsereko, V.L., Iwaasa, A.D., Yang, W., 2001. Effects of an exogenous enzyme preparation on microbial protein synthesis, enzyme activity and attachment to feed in the Rumen simulation technique (Rusitec). Br. J. Nutr. 85, 325-332.

Weber, N.D., Anderson, D.O., North, J.A., Murray, B.K., Lawson, L.D., Hughes, B.G. 1992. In vitro virucidal effects of Allium sativum (garlic) extract and compounds. Planta Med. 58, 417-423. 